\title{
Chemical composition as a criterion in identifying tourmalines from the Ravne pegmatite and surrounding metapelites, Slovenia
}

\section{Kemična sestava kot kriterij za določitev turmalinov v ravenskih pegmatitih in okolnih metapelitih}

\author{
Petra SOUVENT ${ }^{1}$, Anna M. FIORETTI ${ }^{2}$, Giuliano BELLIENI ${ }^{3} \&$ Tadej DOLENEC $^{1}$ \\ ${ }^{1}$ University of Ljubljana, Faculty of Natural Science and Engineering, Aškerčeva 12, 1000 Ljubljana, \\ Slovenia \\ ${ }^{2}$ Centro Studi Geodinamica Alpina CNR, C.so Garibaldi 37, 35137 Padova, Italy \\ ${ }^{3}$ University of Padova, Dept. of Mineralogy and Petrology, C.so Garibaldi 37, 35137 Padova, Italy
}

Key words: Pegmatite, Metamorphic rocks, Tourmaline, Chemical zoning, Slovenia

Ključne besede: pegmatit, metamorfne kamnine, turmalin, kemična conarnost, Slovenija

\begin{abstract}
In the Ravne area (north Slovenia), tourmalines from the pegmatite and the metapelites were studied. All of the examinated tourmalines are members of the schorldravite solid solution series. Most of the tourmalines show optical zoning. Electron microprobe analyses indicate chemical zoning, with low $\mathrm{Ca}, \mathrm{Mg}$ and $\mathrm{Ti}$ within optically distinct core with respect to the rim, for the pegmatite tourmalines, and low $\mathrm{Fe}, \mathrm{Na}$, $\mathrm{Ti}$ and high $\mathrm{Al}, \mathrm{Mg}, \mathrm{Ca}$ and $\mathrm{Mn}$ within optically distinct core with respect to the rim, for the metapelite tourmalines.
\end{abstract}

\section{Kratka vsebina}

Na območju Raven smo preučili turmaline v pegmatitu in metapelitih. Vsi raziskani turmalini predstavljajo šorlitno-dravitno trdno raztopino. Pri večini turmalinov lahko opazujemo optično conarnost. Raziskave s pomočjo elektronskega mikroanalizatorja so pri turmalinih $\mathrm{v}$ pegmatitu pokazale kemično conarnost $\mathrm{v}$ optično različnih jedrih, $\mathrm{z}$ nižjimi vsebnostmi Ca, Mg in Ti glede na robove. Pri turmalinih v metapelitih pa smo v optično različnih jedrih zaznali nižje vsebnosti $\mathrm{Fe}, \mathrm{Na}$, Ti in višje vsebnosti Al, Mg, Ca ter $\mathrm{Mn}$, glede na njihove robove.

\section{Introduction}

Tourmaline is a common accesory mineral with the general formula of $\mathrm{XY}_{3} \mathrm{Z}_{6}\left(\mathrm{~T}_{6} \mathrm{O}_{18}\right)\left(\mathrm{BO}_{3}\right)_{3}(\mathrm{OH})_{4}$. The $\mathrm{X}$ site is usually occupied by $\mathrm{Na}$, but it can contain some amount of $\mathrm{Ca}, \mathrm{Mg}$ and vacancies also (F o i t \& R o s e n b e r g, 1977). Y site can be occupied by large variety of monovalent
(Li), divalent $\left(\mathrm{Fe}^{2+}, \mathrm{Mn}^{2+}, \mathrm{Mg}^{2+}\right)$, trivalent $\left(\mathrm{Al}^{3+}, \mathrm{Cr}^{3+}, \mathrm{V}^{3+}, \mathrm{Fe}^{3+}\right)$ and tetravalent cations $\left(\mathrm{Ti}^{4+}\right.$ ) (F r o n d e l et al., 1966; H e r m o n et al., 1973; Fortier \& D onn a y, 1975; F o it \& R o s e n ber g, 1979). The Z site is typically occupied by $\mathrm{Al}$, but significant amounts of $\mathrm{Mg}, \mathrm{Fe}^{3+}, \mathrm{V}^{3+}$ and $\mathrm{Cr}^{3+}$ can replace $\mathrm{Al}$ (H a w th orne \& Henry, 1999). In the $\mathrm{T}$ site, some $\mathrm{Al}$ can substitute for $\mathrm{Si}$ 
and in the hydroxyl site, $\mathrm{OH}$ - can be substituted by $\mathrm{O}^{-}$or $\mathrm{F}^{-}$(Foit \& Rosenberg, 1979). Tourmaline can be found in granitoid intrusive rocks and their associated pegmatites, aplites, and hydrothermal aureoles, in metamorphic rocks, and in clastic sedimentary rocks.

Tourmaline of the Ravne area (north Slovenia) occurs as an euhedral accesory mineral in pegmatite veins as well as in the metamorphic country rocks. The investigated area is located north of the Periadriatic lineament in the Eastern Alps (Fig. 1). In an area of approximately $40 \mathrm{~km}^{2}$, more than 300 pegmatite veins outcrope, ranging from some centimetres to some metres in thickness. Most of the pegmatite bodies lie concordant within the metamorphic rocks, only a few are discordant ( $\breve{\mathrm{S}} \mathrm{t} \mathrm{r}$ u c l, 1988). Metamorphic rocks are metapelites and metacarbonates with silicate component, represented mostly by biotite and biotitemuscovite gneiss, biotite-amphibole gneiss and calc-silicate slates (M i o č \& Ž n i d a r č i č , 1980). Tourmaline was found in almost all of the pegmatite bodies and in some of the metamorphic country rocks, namely only in the metapelites.
Electron microprobe data on zoned tourmalines are reported in this paper in order to investigate the difference between tourmalines from the pegmatite and tourmalines from the metapelites.

\section{Experimental methods}

Chemical analyses on mineral phases were carried out at the »Centro di Studi per la Geodinamica Alpina " of CNR in Padova. Wavelength dispersive analyses were obtained using a CAMECA-CAMEBAX 799 electron microprobe operating at $15 \mathrm{kV}$ with $15 \mathrm{nA}$ sample current. Counting times were 10 seconds for peak and 5 seconds for background for $\mathrm{F}, \mathrm{Na}, \mathrm{K}, \mathrm{Mg}, \mathrm{Al}, \mathrm{Si}, \mathrm{Fe}$; and 20 seconds for peak and 10 seconds for background for $\mathrm{Ca}, \mathrm{Ti}, \mathrm{Cr}, \mathrm{Mn}, \mathrm{Zn}$. PAP correction programme was used to convert x-ray counts into oxide weight percentages. Well characterised minerals and synthetic compounds were used as standard: wollastonite (Si, Ca), corundum (Al), albite $(\mathrm{Na})$, orthoclase $(\mathrm{K})$, periclase $(\mathrm{Mg})$, iron oxide $(\mathrm{Fe})$, $\mathrm{MnTiO}_{3}$ (Mn, Ti), chromite (Cr), fluorapatite $(\mathrm{F})$ and sphalerite $(\mathrm{Zn})$. The analyses

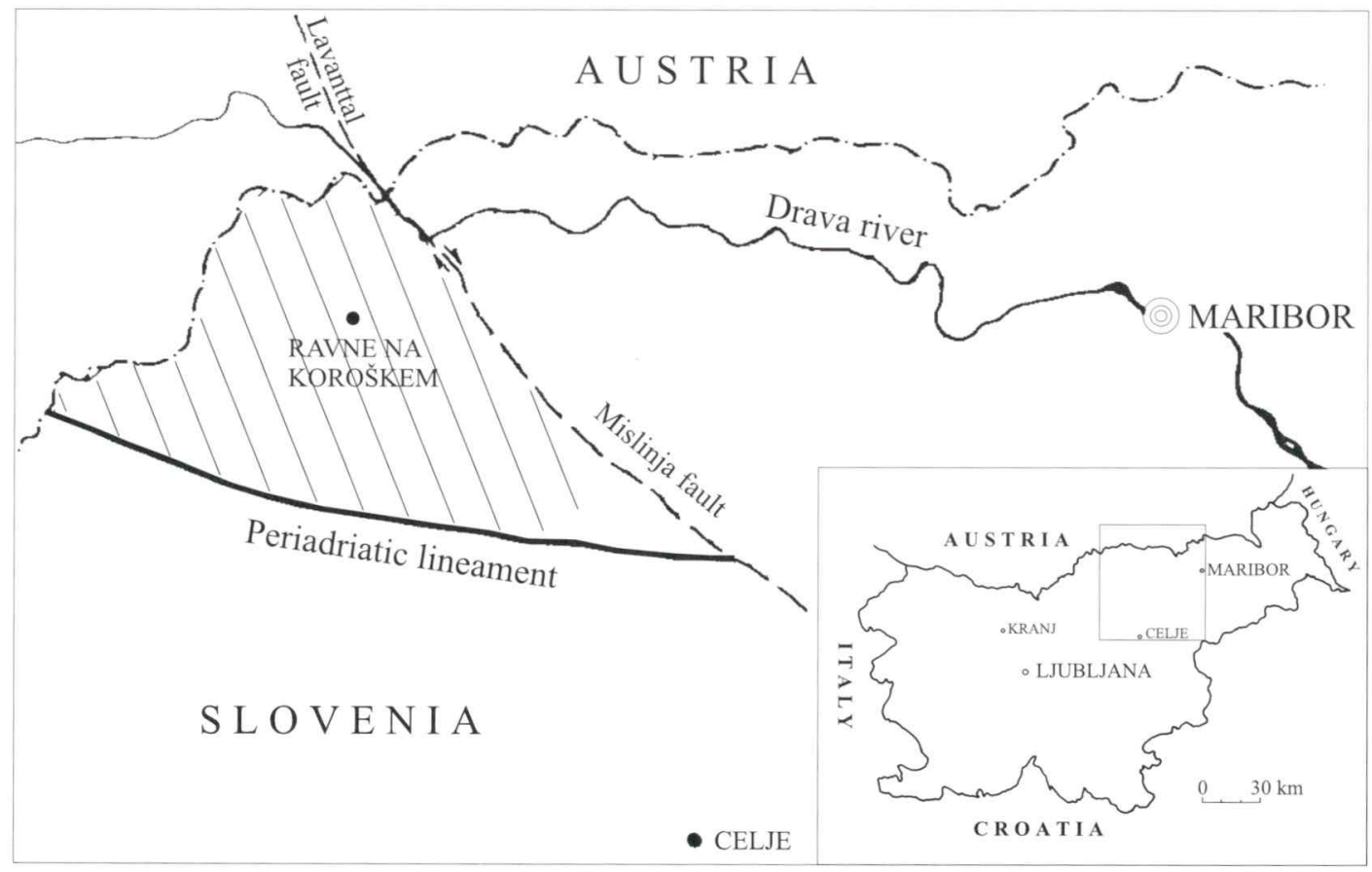

Fig. 1. Map showing the location of investigated metamorphic rocks and pegmatites (hatched area). 
are precise to within 1\% for major elements and $3 \%$ for minor elements. The structural formula was calculated with the »Formula1« programme provided by SAMxFrance (Support for Application in x-ray Microanalyses) on the basis of 24.5 oxygens and $4 \mathrm{H}_{2} \mathrm{O} . \mathrm{B}_{2} \mathrm{O}_{3}$ was calculated by stoichiometry.

\section{Results and discussion}

All of the Ravne tourmalines are members of the schorl-dravite solid solution series. Tourmalines from pegmatite are closer to the schorl end member (the Y-site cation is predominantly $\mathrm{Fe}^{2+}$ ) while tourmalines from metamorphic rocks have more dravitic component and are closer to the dravite end member (the Y-site cation is predominantly $\mathrm{Mg}$ ). On the Al-Fe-Mg (Fig. 2) and Ca-Fe$\mathrm{Mg}$ (Fig. 3) ternary classification diagram of $\mathrm{H}$ e n r y and Guidot ti (1985) tourmalines from pegmatite fall in the field of Li-poor granitoids and their associated pegmatites and aplites. Tourmalines from metapelites fall in the field of metapelites and metapsammites coexisting with an $\mathrm{Al}-$

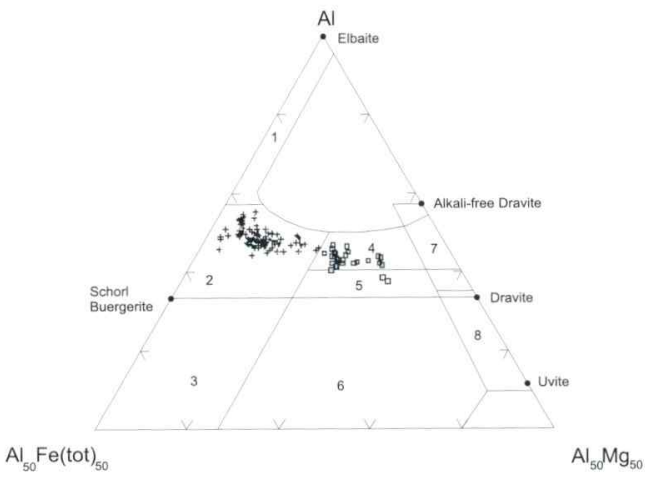

Fig. 2. Al-Fetotal-Mg diagram for Ravne tourmalines. Field numbers as in Henry and Guidotti (1985): (1) Li-rich granitoid pegmatites and aplites, (2) Li-poor granitoids and their associated pegmatites and aplites (+), (3) $\mathrm{Fe}^{3+}$-rich quartz-tourmaline rocks (hydrothermally altered granites), (4) Metapelites and metapsammites coexisting with an Al-saturating phase ( $\square$ ), (5) Metapelites and metapsammites not coexisting with an Al-saturating phase, (6) $\mathrm{Fe}^{3+}$ - rich quartz-tourmaline rocks, calc-silicate rocks, and metapelites, (7) Low-Ca metaultramafics and $\mathrm{Cr}$, V-rich metasediments, and (8) Metacarbonates and meta-pyroxenites. Fields 4 and 5 overlap with field 7 .

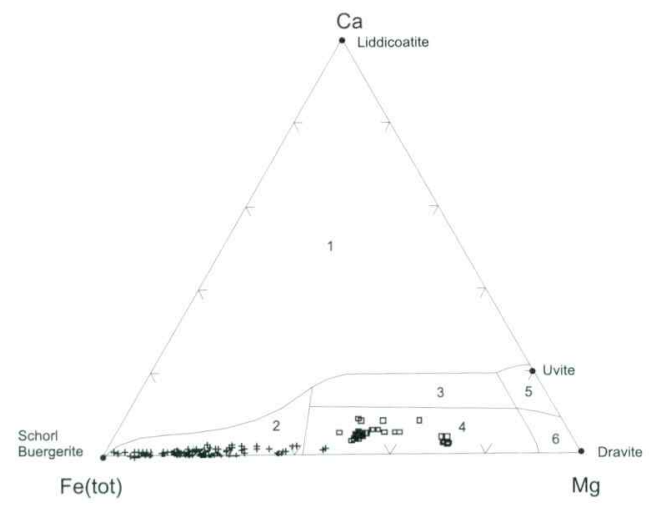

Fig. 3. Ca-Fetotal-Mg diagram for Ravne tourmalines. Field numbers as in Henry and Guidotti (1985): (1) Li-rich granitoid pegmatites and aplites, (2) Li-poor granitoids and their associated pegmatites and aplites (+), (3) Ca-rich metapelites, metapsammites, and calc-silicate rocks, (4) Ca-poor metapelites and metapsammites, and quartz-tourmaline rocks ( $\square)$ ), (5) Metacarbonates, (6) Metaultramafics. Field 6 overlap with field 4

saturating phase (Fig. 2) and in the field of Ca-poor metapelites, metapsammites, and quartz-tourmaline rocks (Fig. 3).

Tourmalines from pegmatite. The diameter of the tourmaline crystals ranges from $0,1 \mathrm{~mm}$ to $40 \mathrm{~mm}$ and the length from 0,5 $\mathrm{mm}$ to $150 \mathrm{~mm}$. Most of the tourmaline grains are fractured. Fractures are filled with fine-grained quartz, muscovite (sericite) or feldspar. Larger crystals are clearly zoned under the microscope. Cores are light to greyish-blue while the rims are darker - olive green, greenish-, brownish-, or dark blue. The colour is usually not gradational from core to rim and involves sharp optical discontinuities. Tourmaline grains showing these optical discontinuities may have either irregular cores, which are not necessarily in the centre of the tourmaline, and euhedral rims, or both euhedral cores and rims. Some smaller tourmaline grains are optically unzoned.

Tourmalines with euhedral cores and rims display chemical zoning, with $\mathrm{Ca}, \mathrm{Mg}$, $\mathrm{Ti}, \mathrm{Zn}$ increasing, and $\mathrm{Mn}, \mathrm{Na}, \mathrm{Al}$ decreasing from the rim towards the boundary of the optically distinct core. Within the optically distinct core, $\mathrm{Ca}, \mathrm{Mg}$ and $\mathrm{Ti}$ decrease abruptly, $\mathrm{Zn}$ and $\mathrm{Mn}$ do not show any specific trends, $\mathrm{Na}$ slightly decreases and $\mathrm{Al}$ slightly may increase or decrease (Fig. 4). 

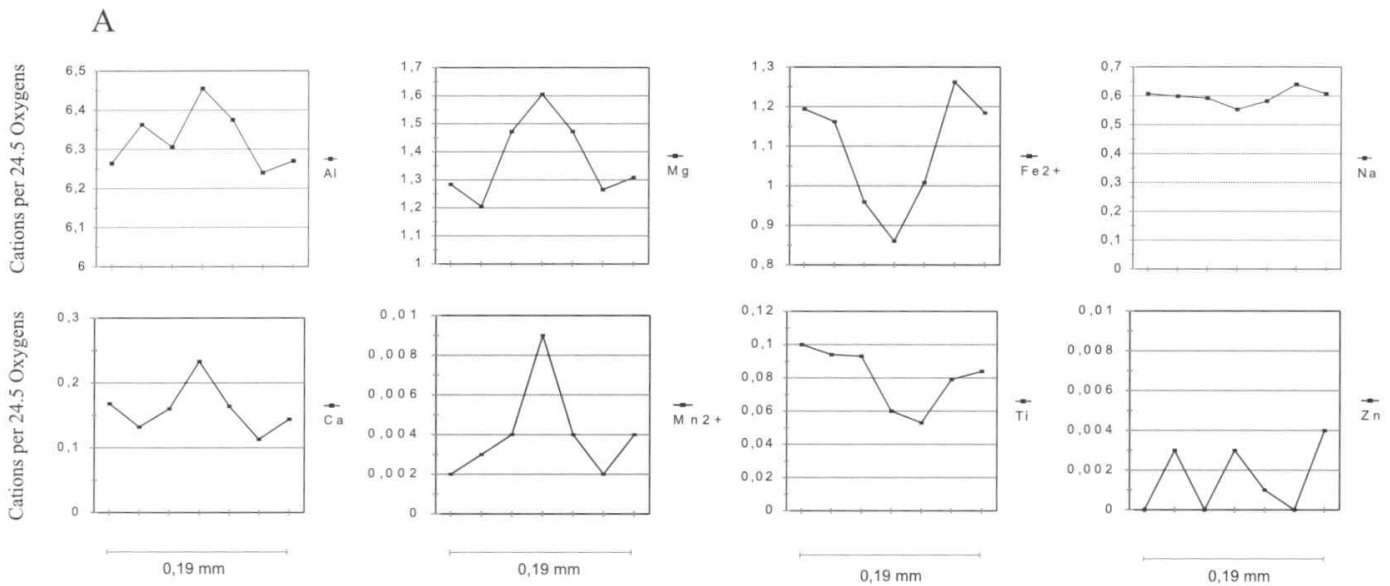

B
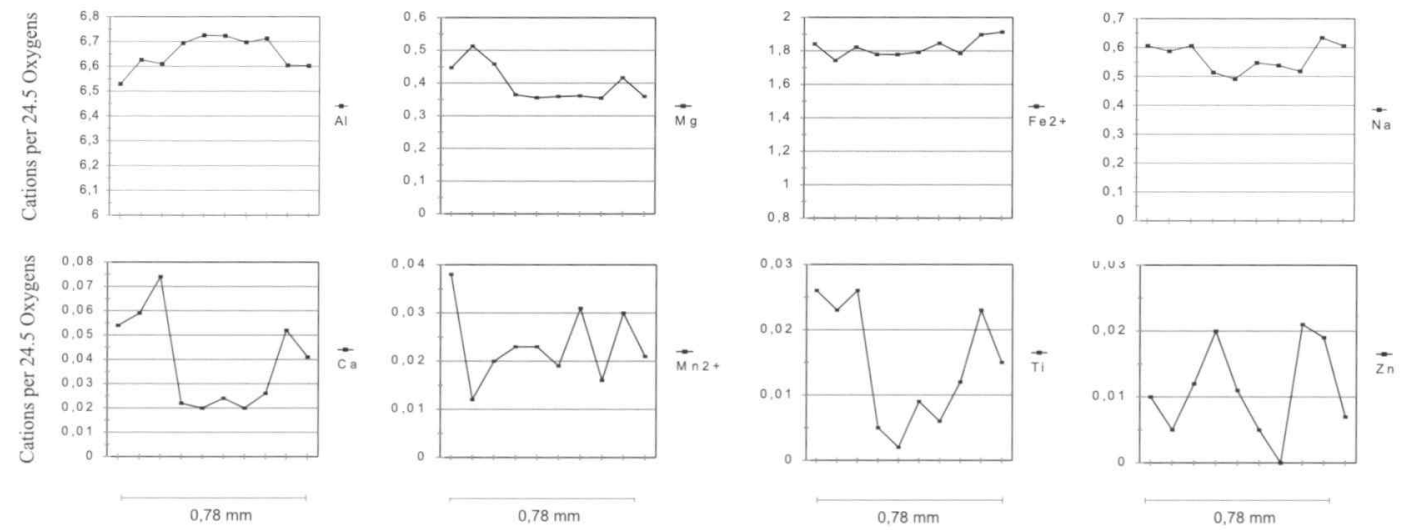

Fig. 4. Electron microprobe traverses from rim to rim of zoned tourmalines from metapelite (A) and pegmatite (B)

Tourmalines from metapelites. Tourmalines are subhedral to euhedral and smaller than tourmalines from pegmatite. The diameter of the grains ranges from 0,01 $\mathrm{mm}$ to $0,2 \mathrm{~mm}$ and the length from $0,04 \mathrm{~mm}$ to $2,5 \mathrm{~mm}$. Some of them are fractured. The optical zoning is not very clear, transition between colours are blurred. The cores are usually light greenish-brown, very pale brown or yellowish-brown. The rims are brown or dark greenish-brown.

Chemical zoning indicates $\mathrm{Al}, \mathrm{Mg}, \mathrm{Ca}$, $\mathrm{Mn}$ enrichment and $\mathrm{Fe}$, Ti, $\mathrm{Na}$ depletion in the cores with respect to the rims. Zn does not show any specific trends. Representative microprobe analyses of the zoned tourmalines are reported in Table 1.

According to $\mathrm{Hin}$ terle chner- $\mathrm{R}$ av $\mathrm{nik}$ (1984), tourmalines in the pegmatite probably formed during the anatexis of the metamorphic rocks in the sillimanite field of the amphibolite facies. Rims of these tourmalines could be younger and may be related with the last phase of the metamorphism. The drop of pressure and of temperature, together with the influx of water was the cause of this retrograde metamorphism. In this stage of the recrystallisation, boron was also present and numerous euhedral tourmalines were formed in the metapelites (H in terle c hner - R a vn i k, 1984). Alternatively, the tourmalines in the pegmatite could have crystallized from pegmatite fluids related to the near granites of the Northern Karavanke igneous belt. Further investigations are planned to better constrain the genesis of these tourmalines. 
Table 1. Representative microprobe analyses of tourmaline from pegmatite (P) and metapelite (M); c-core, r-rim, (c)-calculated.

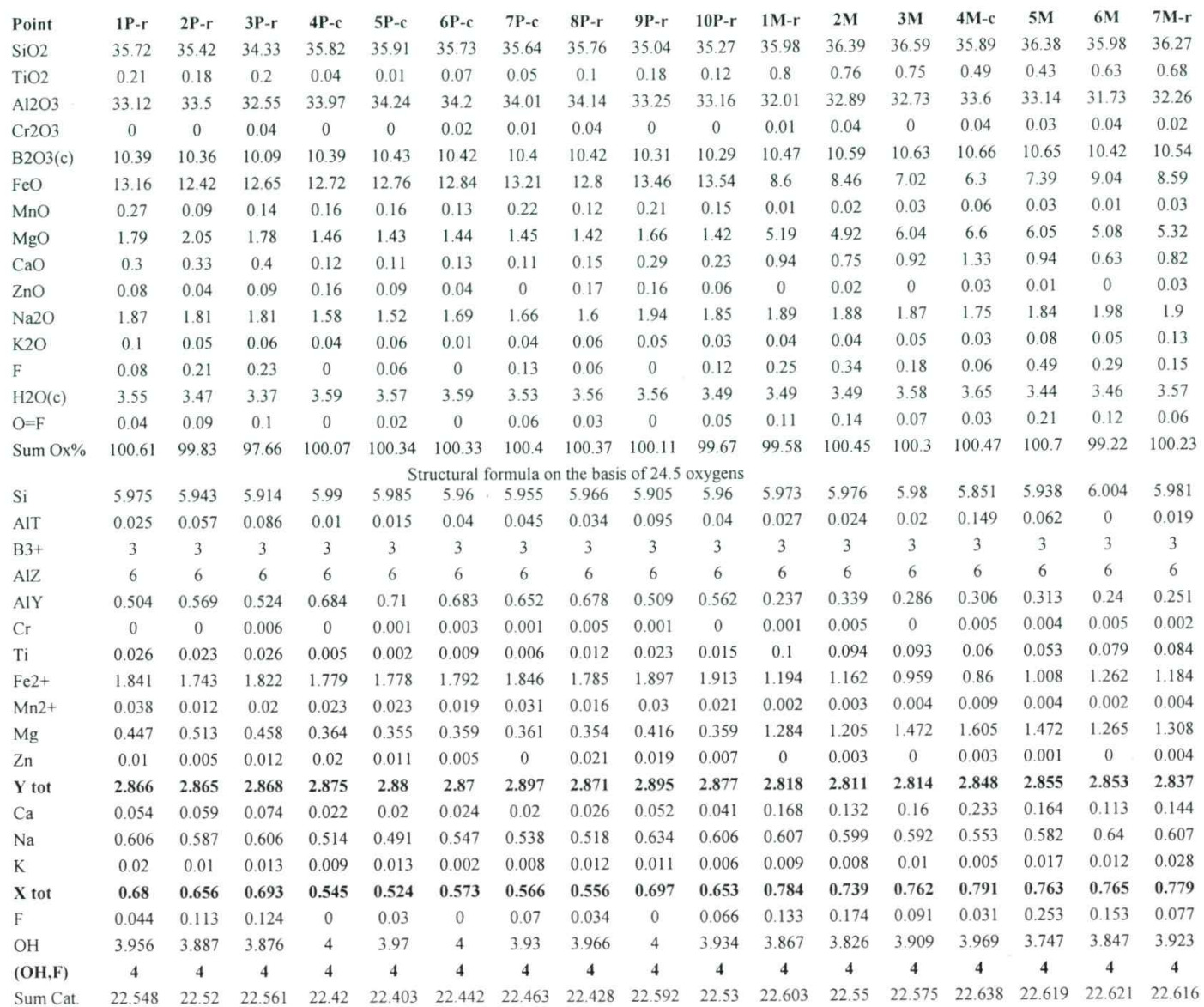

\section{References}

F or ti e r, S. \& D o n n a y, G. 1975: Schorl refinement showing compositional dependence of the tourmaline structure.- Canadian Mineralogist, 13, 173-177, Montreal.

F o i t, F. F. \& Jr., R o s e n b e r g, P. E. 1977: Coupled substitutions in the tourmaline group.Contributions to Mineralogy and Petrology, 62, 109-127, Berlin.

F o i t, F. F. \& Jr., R o s e n b e r g, P. E. 1979: The structure of vanadium-bearing tourmaline and its implications regarding tourmaline solid solutions.- American Mineralogist, 64, 788-798, Washington.

Frond e l, C., B i e d l, A. \& I t o, J. 1966: New type of ferric iron tourmaline.- American Mineralogist, 51, 1501-1505, Washington.

H a w th or n e, F. C. \& H e n r y, D., J. 1999. Classification of the minerals of the tourmaline group.- European Journal of Mineralogy, 11, 201-215, Stuttgart.

H e n r y, D. J. \& G u i d o t t i, C. V. 1985: Tourmaline as a petrogenetic indicator mineral:
An example from the staurolite-grade metapelites of NW Maine.- American mineralogist, 70,1-15, Washington.

H e r m o n, E., S i m k i n, D. J., D o n n a y, G. \& $\mathrm{M}$ u i r, W. B. 1972: The distribution of $\mathrm{Fe}^{2+}$ and $\mathrm{Fe}^{3+}$ in iron-bearing tourmalines: A Mössbauer study.- Tschemarks Mineralogische und Petrographische Mitteilungen, 19, 124-132, Wien.

H int e r l e c hner - R a vn i k, A. 1984: Regional metamorphism of pelites and calc-silicate rocks in the area north of Ravne na Koroškem.- Geologija, 27, 171-199, Ljubljana.

M i o č, P. \& Ž n i d a r č i č, M. 1980: Tolmač za list Ravne na Koroškem. - Zvezni geološki zavod, $61 \mathrm{p} .$, Beograd.

S t r u c l, I. 1988: Raziskava pegmatoidov v okolici Raven na Koroškem. Končno poročilo poldetaljnih raziskav, projekt C7-7233-539.Arhivsko poročilo, Ekonomski Center Maribor, 47p., Ravne. 